late Prof. H. G. Jackson. In 1943 he was made head of the Department and professor of zoology in 1947. Prof. Graham is a governor of Birkbeck College. As chairman of the Board of Studies in Zoology, and of the Board of Examiners in Zoology, he has given valuable services to the University of London. Prof. Graham can look back with pride on his achievement in keeping the Department at Birkbeck College going during the War. In 1940 the Zoology Department was destroyed by bombing, though most of the teaching specimens were salvaged. The Department was set up in the condemned building of Graystoke, and when further bombing restricted its activities, classes were carried on in a cellar, and on several occasions in the open air. He preserved the continuity of the Department through every calamity and raised it to its present high status-a department consisting almost exclusively of part-time students, of whom one-fifth are engaged in research for higher degrees. Prof. Graham's research work has been on the functional anatomy of molluses, with special reference to feeding habits, and the structure and function of the alimentary canal. He has recently been awarded the Keith Prize of the Royal Society of Edinburgh for the period 1949-51.

\section{Sir George Thomson, F.R.S.}

A FAREWELI dinner was held on June 24 at the Imperial College in honour of Sir George Thomson, who after twenty-two years as head of the physics department is leaving on August 1 to become Master of Corpus Christi College, Cambridge. The Rector of the Imperial College, Sir Roderic Hill, presided at the dinner, and the Governing Body was represented by its chairman, Viscount Falmouth. Nearly one hundred people attended, representative of present and past members of the staff and the research students; and on their behalf a presentation was made to Sir George of a watchmaker's lathe, this being suitable for the miniature model-making which is Prof. Thomson's favourite hobby. Prof. W. D. Wright, speaking on behalf of the departmental staff, recalled that it was twenty-five years ago, almost to the day, that a letter had appeared in Nature entitled "Diffraction of Cathode Rays by a Thin Film"; that letter marked the beginning of Sir George's well-known researches in electron diffraction. Since 1930, at Imperial College, Sir George had directed notable researches in electron diffraction, nuclear physics and cosmic rays, and he had also given valuable service to the Government as a scientific adviser, both during and after the War. Many personal tributes were paid to Sir George by subsequent speakers, who included the Rector, Viscount Falmouth, Prof. H. Dingle and Prof. H. Levy. They emphasized in particular Sir George's penetrating scientific insight, and the deep respect which he had won from all associated with him. Just as his distinguished father, Sir Joseph Thomson, had been affectionately known in his laboratory as "J.J.", so Sir George was always referred to as "G.P.". He takes with him to Cambridge the good wishes of all at the Imperial College of Science and Technology,

\section{Peter Artedi : A Contemporary of Linnæus}

THE yearbook for 1950-51 of the Swedish LinnéSällskapets (Årg. 33-34, 1950-51 ; pp. iii +188 ; Uppsala : Almquist and Wiksell, 1951) includes two contributions by Dr. O. Walde and Prof. H. Engel dealing with the biography of Peter Artedi, the friend and fellow student of Linnæus. Artedi was accidentally drowned in 1735 before completing his important work on ichthyology on which his reputation rests. His manuscripts were saved by Linnæus, who edited and published the "Ichthyologia" in 1738, adding a brief biography of the author. Very little is known of Artedi personally, and only one of his letters has survived. Dr. Walde has discovered, in the Royal Library at Stockholm, a small volume dealing with alchemy, botany and agriculture, which was recognized as the work of Artedi. Prof. Engel relates that Artedi lived a lonely life, going to the tavern from 3 to 9 p.m., working from 9 p.m. to 3 a.m., and sleeping from 3 a.m. to noon. This article comments on some of the legal documents connected with Artedi's death and on the personal effects left by him.

\section{A New Anti-malarial Drug: 'Daraprim'}

'DARAPRIM', a new anti-malarial drug, has recently been put on the market by Messrs. Burroughs Wellcome and Co. It is $2: 4$-diamino-5-p-chlorophenyl6 -ethylpyrimidine, and is the most active of a large series of substituted $2: 4$-diamino-pyrimidines which have been synthesized and tested against laboratory infections of Plasmodium gallinaceum in chicks and $P$. berghei in mice (Falco et al., Brit. J. Pharmacol., 6,185 ; 1951). Trials in quiescent cases of human malaria have been reported by Archibald (Brit. Med. $J .$, ii, $821 ; 1951$ ), and in overt infections of $P$. falciparum and $P$. malarioe in man by McGregor and Smith (Brit. Med.J., i, 730; 1952). They concluded that it has a powerful action on schizonts and a lesser and inconstant action on trophozoites. It acted as swiftly in non-immunes as in others possessing partial immunity; it is tasteless and no toxic reactions of any kind were observed. The drug is an effective suppressant of $P$. falciparum infections, even in doses as small as $5 \mathrm{mgm}$. daily. Goodwin (Brit. Med. J., $i, 732$; 1952) took this amount daily for one year. During this time he deliberately exposed himself to the bites of four mosquitoes later shown to be infected with $P$. falciparum. He also slept without a mosquito net for six months while in West Africa. Throughout this period there were no toxic manifestations, and no abnormalities were produced in the blood, bone marrow, or urine. To each of a group of volunteers in England, $50 \mathrm{mgm}$. of the drug was given twice weekly for three months. Again there were no demonstrable effects on the urine, blood, or erythrocyte sedimentation-rate. Although it is too early to assess the value of this drug, and there are as yet no reports on its action in $P$. vivax infections, its schizonticidal efficiency in $P$. falciparum and $P$. malarice infections appears to lie between that of paludrine and chloroquine, and it may prove to be a highly efficient malarial suppressant.

\section{Geophysical Research Aboard the R.R.S. Dis- covery II}

THE R.R.S. Discovery II has recently set sail on the second of its current series of research cruises (see Nature, May 24, p. 866), and is expected to be at sea for five to six weeks, going about six hundred miles seaward. The main purpose of the cruise is to elucidate the structure of the sea-bed by taking samples of the top strata and by seismic refraction 'shooting' at short and long ranges. The geological sampling will be carried out both in shallow and deep water by means of specially designed coring-tubes, 